\title{
SYSTEMATIZATION OF THE CREATIVITY DEVELOPMENT METHODS OF SCIENTIFIC AND PEDAGOGICAL WORKERS IN THE POSTGRADUATE EDUCATION SYSTEM
}

\section{СИСТЕМАТИЗАЦІЯ МЕТОДІВ РОЗВИТКУ КРЕАТИВНОСТІ НАУКОВО-ПЕДАГОГІЧНИХ ПРАЦІВНИКІВ У СИСТЕМІ ПІСЛЯДИПЛОМНОї ОСВІТИ}

УДК 37.036.5:374.7

DOI https://doi.org/10.32843/2663-

6085.2019.12-1.18

\section{Illiakhova M.V.,}

$\mathrm{PhD}$, Associate Professor

at the Department of Philosophy

and Adult Education

of University of Educational Management

of National Academy of Sciences

of Ukraine
In the article has been conducted the systematic analysis of the methods of creativity development of the scientific and pedagogical workers in the system of postgraduate education. The four basic groups of methods of creativity development of the scientific and pedagogical worker are determined, in particular methods of stimulation of creative activity and activation of thought activity, non-algorithmic methods, algorithmic methods, organizational measures. It is found that methods of professional development of creativity of scientific and pedagogical worker represent an effective experience of adaptive application of creative competences, that have been formed in the process of solving problem-searching and innovative-research tasks, removal of barriers of stereotyped thinking and development of cognitive flexibility. Harmonious implementation of methods for developing the creativity of a scientific and pedagogical worker at all stages of the course and inter course period enables the innovative, creative, heuristic achievements of a specialist at various stages of his professional activities. First of all, it is creation of author's professional products and achievement of high results of scientific and pedagogical activity in the process of realization of creative, intellectual, operational skills of a specialist.

Key words: andragogic cycle, innovative activity, creativity, creative methods, postgraduate education.

у статті проведено системний аналіз методів розвитку креативності науковопедагогічного працівника у системі післядипломної освіти. Визначено чотири базові групи методик розвитку креативності науково-педагогічного працівника, зокрема методи: стимуляції креативної активності, активізації мисленнєвої діяльності, неалгоритмічні, алгоритмічні та організаційні методи. Встановлено, що методи профеесійного розвитку креативності науковопедагогічного працівника презентують ефективний досвід адаптивного застосування креативних компетенцій, срормова- них у процесі вирішення проблемно-пошукових та інноваційно-дослідних завдань, зняття бар'єрів стереотипного мислення та розвитку когнітивної гнучкості. Гармонійна реалізація методів розвитку креативності науково-педагогічного працівника на всіх етапах курсового і міжкурсового періоду уможливлює інноваційні, творчі, евристичні досягнення срахівця на різних етапах його просресійної діяльності. Передусім, це створення авторських профеесійних продуктів і досягнення високих результатів науковопедагогічної діяльності у процесі реалізаціі творчих, інтелектуальних, операційних здібностей фрахівця.

Ключові слова: андрагогічний цикл, інноваційна діяльність, креативність, креативні методи, післядипломна освіта.

В статье проведен системный анализ методов развития креативности научно-педагогических работников в системе последипломного образования. Определены четыре базовые группы методик развития креативности научно-педагогического работника, а именно методы: стимуляции креативной активности, активизации мыслительной деятельности, неалгоритмические и алгоритмические, а также организационные методы. Гармоничная реализация методов развития креативности научно-педагогического работника на всех этапах курсового и межкурсового периода делает возможными инновационные, творческие, эвристические достижения специалиста на разных этапах его профессиональной деятельности. Прежде всего, это создание авторских профрессиональных продуктов и достижение высоких результатов научно-педагогической деятельности в процессе реализации творческих, интеллектуальных, операционных способностей специалиста

Ключевые слова: андрагогический цикл, инновационная деятельность, креативность, креативные методы, последипломное образование.
Target setting. Modern national educational policy is focused on the education of innovative, creative personality, whose activity will be effective in the space of information changes. It is the creative person that enables an innovative modernization of the economy of the network society, becomes its fundamental center, the semantic core, the driving force and the goal of continuous social development. In accordance with the Laws of Ukraine "On Education" (2017), "On Higher Education" (2014), the Concept "New Ukrainian School" (2017), the Resolution of the Cabinet of Ministers of Ukraine "On Approval of the National Qualifications Framework" (2011 ), the
Decree of the President of Ukraine "On the National Strategy for the Development of Education in Ukraine until 2021" (2013), one of the priorities of national education is the formation and development of a creative person who can innovate, learn throughout life, be motivated, entrepreneurial, mobile in his own professional development.

An effective implementation of the strategy of innovative development of national education can be carried out by a modern, creative scientific-pedagogical worker who possesses transdisciplinary knowledge, who is capable of working in the format of innovation-creative search, who is experiment- 
oriented and ready for innovations and is motivated on continuous informational self-renewal of their own professional development. This challenges postgraduate education institutions to create and implement diverse, differentiated techniques and technologies, that would boost the improvement and development of the creativity of scientific and pedagogical workers.

Analysis of recent research and publications. The analysis of approaches to the definition of creativity has found that some scholars understand it as a specific ability, due to the presence and combination of different personal qualities (A. Matyushkin, L. Mitin, A. Smirnov); the ability to transform, update the existing experience (B. Lomov, A. Karpov, Y. Ponomariov); integral quality of the personality, which unites the cognitive and personal sphere (D. Bogoyavlenska, V. Druzhinin, M. Kashapov, V. Shadrikov); a specific form of mental activity, a complex and multidimensional phenomenon that has its own structure (T. Barysheva, E. Torrens). Also, creativity is identified with the maximum level of development of intellectual abilities (O. Dyachenko, J. Piaget, O. Tikhomirov, M. Cold). Analyzing the creative abilities of pedagogical workers, native scientists (N. Bilyk, A. Vishnevsky, V. Ilyin, V. Kremen, L. Koretska, V. Levenets, L. Levchuk, M. Lipin, A. Markov, O. Shamray) note the high role of intuition in the process of so-called "scientific creativity" as a result of mental activity, that enables to shorten the path of knowledge on the basis of rapid logical-unconscious understanding of the situation and making the right decision.

Novelty of research. Despite the considerable amount of scientific researches and the proper working out, by scientists, of various aspects of problems that are close to the one discussed, the development of creativity of scientific and pedagogical workers in conditions of continuous education was not the subject of separate conceptual studies. It is characterized by variation of approaches, ambiguous interpretation of many aspects. Among the scholars, it is commonly believed that the concept of "creativity" is tangent to the concept of "creativeness". Also, much of the works are often devoted to separate issues of professional development of scientific and pedagogical workers. Therefore, there is a lack of targeted systemic research, on the development of creativity of scientific and pedagogical workers in the system of postgraduate education. As a result, there is a critical shortage of specialists in Ukraine that would meet the requirements of the rapid pace of development of educational innovations.

The purpose of the paper is to systematize numerous methods of developing the creativity of scientific and pedagogical workers in the system of postgraduate education. To achieve the purpose of research were used methods of problem-target systematic analysis - for comparing and contrasting views in philosophy, pedagogy, psychology, substan- tiation of essence, methods of creativity development of scientific and pedagogical workers, as well as were used the methods of synergistic, functional and structural modeling - for the working out an individual and socially orientated trajectory of development of creativity of scientific and pedagogical workers.

Results of the research. In our opinion, the creativity of a scientific and pedagogical worker is a systematic, multifactorial, integrative unity of cognitive knowledge, operational skills, praxeological skills, values, acmeological guidance of a specialist that enables his effective scientific-research activities, provide a systematic, innovative upgrade of the content and methods of the educational process, realize the potential of diagnostics and analysis of educational and cognitive activity, form the skills for self-actualization, self-organization, self-determination, develop lateral potential, flexible, innovative thinking, social and professional mobility, actualize the need for the self-education, the ability to respond to unpredictable, variable conditions of professional activity and to obtain the dynamics of their own life and professional opportunities. Harmonious correlation of the components and professional qualities of a scientific and pedagogical worker forms a higher level of development of his professional creativity. Taking this into account, postgraduate education should provide appropriate organizational and pedagogical conditions for the development of professional creativity of scientific and pedagogical workers as an inseparable condition for improving the efficiency of their professional activities in modern conditions.

Coherent development of creativity of scientific and pedagogical workers is possible only in the unity of pre-course, advanced training (basic) and post-course (implementation) stages of professional activity, which correlates with the certification period of a scientific and pedagogical worker. It is in the andragogic cycle, according to T. Sorochan [4], where the structural and meaningful unity of the courses of advanced training, scientific and methodological and research works, and self-education of an adult in the process of professional growth are realized. Therefore, the implementation of creative practices in the andragogic cycle is not limited only to the presence of a specialist in advanced training courses. Taking this into consideration, the strategic orientation of creative practices is the combination of personal, acmeological development of a specialist with an increase of his professional potential.

The structure of creative practices is formed by the latest techniques and technologies for the development of nonlinear, divergent, innovative and creative thinking. The purpose of each method is a production of original, alternative levels of non-standard problem solving in scientific and pedagogical activities. The key task is to remove the barriers of stereotyped thinking and the development of cognitive flexibility, which forms 
the skills of rapid reaction to non-standard situations, develops creative-reflexive activity and the ability to quickly switch from one guideline to another, turning off the automatic reactions of thinking. Accordingly, creative practices are divided into following basic groups of techniques, in particular: 1) methods of stimulation of creative activity and activation of thinking activity; 2) non-algorithmic methods; 3) algorithmic methods; 4) organizational activities.

The first group includes a variety of techniques for stimulating the psyche, developing creative potential and activating the thinking activity that is realized on the individual and group levels. These are heuristic techniques aimed at forming in the adult person a positive motivation, sustained cognitive interest, as well as those qualities of thinking, on which depends on the successful solving of creative tasks. In the complex of heuristic techniques one should distinguish: 1) A thought-based experiment that is based on the substitution of real objects by their relative samples, analogues. In such way it is possible to trace the characteristic features, connections, trends of the studied processes, to assess their condition, make a prediction, take a well-grounded decision. 2) Combination is a fundamental heuristic trick, because it is based on the separation of existing systems and the creation of new structures from their elements. New combinations of known elements lead to the creation of things that have fundamentally new, amazing properties. 3) Inverse thinking is a method that involves the rapid change of thinking of an adult person from the usual direction to the opposite, destroying the template guidelines in solving the problem. 4) Dialogueness of thinking involves the orientation of the adult person on several decisions, among which she chooses the best. At the same time, the solution of the problem involves the search, and the ambiguity of the ways of its solution, by the simultaneous nomination of several hypotheses, or the collision of different, sometimes opposing thoughts. 5) Analogy, as a heuristic method, is based on a comparison of structures, functions, principles, as well as on the definition of significant similarity and the transfer of these features into a new solution.

Activation of thinking activity should take place in several directions, in particular: stimulation of thinking activity with the help of advice as actualization of new and existing knowledge and experience; the formation of flexibility of thinking through the implementation of activities in unconventional situations, in complicated conditions; formation of a general positive attitude to the process of solving problems. "The advantages of the first group of methods for stimulating the psyche and activating the thinking activity are universal accessibility, individuality, simplicity" [2, p. 24]. The disadvantages of this group of techniques are randomness of the obtained results, unpredictability. Unlike the algorithms, heuristic techniques, though not guaranteeing the integrity of the solution, still allow to operate under uncertainty, when a person does not know yet the essential features of the components, which leads to the solution of the problem. But these techniques contain only general guidelines that help in finding alternative ways to solve the problem.

The second group combines non-algorithmic techniques for the development of creativity, in particular: brainstorming, the method of synectics, the method of focal objects, the method of danetics, morphological analysis and their numerous combinations. All non-algorithmic techniques are aimed at generating as many variants as possible as well as their alternatives for solving the problem. Analyzing these methods, JK Jones notes that "thinking about designing as a solution to a problem means using the frozen metaphor to the living process and forget that design is not aimed at correcting errors, but on the recognition of new opportunities and the discovery of our attitude towards them" [1, p. 124]. It should be noted that all non-algorithmic techniques are peculiar psychological tools, the choice of which depends on the conditions, goals and objectives of the subject of creative activity. The second group of techniques is aimed at eliminating of hopeless situations by distinguishing systemic links, features, characteristics of the problem under investigation, the formation of new combinations, and the production of creative ideas. Nellogometric techniques help to solve relatively simple tasks, increase the number of new ideas, they are available in the development and use and are usually based on the collective experience of actors.

In the practice of creative activity, algorithmic methods are found to be effective enough, including algorithms for solving inventive problems (G. Altshuller), "decision tree" (E. Hunt, J. Merin, F. Stone) "garlands of randomness and associations" (G. Bush). The algorithmic group of methods combines structured operations systems, which provide an infallible solution to a certain class of problems. "Mastering these techniques not only allows to solve problems effectively and correctly, but also enables the construction of new methods for solving complex ones" [3, p. 253]. Thus, the development of the ability to comprehensively analyze the conditions of the problem and to form models for the classification of random decisions forms the flexibility of thinking. The methods of the algorithmic group contribute to the improvement of the organization of the thinking process in general, but ignore the development of tools that are aimed at actualizing the possibilities of the subject in solving the untypical, creative by content tasks, as well as the motives for the implementation of innovation activity. Also, the possibility of solving new problems using methods of algorithmic type is limited. Moreover, under certain circumstances, they can slow down the development of productive thinking, since the subject 
is accustomed to working on existing models. Therefore, the use of these techniques must necessarily be combined with methods of heuristic type.

Activation of the creative activity of scientific and pedagogical workers is impossible without the creation and improvement of various external conditions for the organization of creative process in institutions of postgraduate education. Therefore, the formation of the socio-psychological climate, the functional comfortable conditions for mental work, rational selection of information, the organization of methodological, information and communication support of creative development of specialists in educational models of courses of advanced training and intercourse period as a single andragogic cycle will promote creative and acmeological self-development and self-education andragogues-practitioners. Consequently, the organizational group of methods unites: various forms of scientific-methodical polylogue in interactive formats, sessions of selectors, trainings, workshops, round tables, conferences, webinars, chats, videoconferences, on-line studios, pedagogical webquests, etc. The advantage of these measures is the fundamental possibility of solving often "explosive" immediate problem, but on the other hand the significant disadvantages include great resource and time spending and the lack of qualitatively new ideas.

Conclusions and perspectives of further research. As a result of the research, four basic groups of techniques for developing the creativity of a scientific and pedagogical worker were identified, in particular methods of stimulating creative activity and activation of thinking activity, non-algorithmic methods, algorithmic methods, organizational measures. It is established that the methods of professional development of creativity of a scientific and pedagogical worker present an effective experience of adaptive application of creative competences, formed in the process of solving problem-solving and innovative research tasks, removing barriers stereotyped thinking and development of a cognitive flexibility. Harmonious implementation of methods for developing the creativity of a scientific and pedagogical worker at all stages of the course and between the course period enables the innovative, creative, heuristic achievements of a specialist at various stages of his professional activity. First of all, it is creation of author's professional products and achievement of high results of scientific and pedagogical activity in the process of realization of creative, intellectual, operational skills of a specialist. So, the creativity of the scientific and pedagogical worker in the system of post-graduate education enables their effective research activities, implements the potential of diagnosis and analysis of educational and cognitive activity, forms their skills of self-actualization, self-organization, self-determination and practical mastering of the dynamics of their own life-professional skills and opportunities. To implement these guidelines, postgraduate education should provide: continuous scien- tific and methodological support for the professional development of creativity of scientific and pedagogical workers; realization of modern creative methods of professional improvement and professional development of scientific and pedagogical workers in accordance with the requirements of innovative development of society; provide a forward-looking character of the professional development of scientific and pedagogical workers to the needs of reforming of the national education system; strengthen the axiological and creative components of the content of the advanced training; promote the innovative activity of scientific and pedagogical workers; ensure the integrity of the course and inter-course stages of advanced training as a coherent andragogic cycle; develop multi-level, alternative models of professional development of scientific and pedagogical workers taking into account their professional experience, educational level of individual guidelines; introduce innovative forms of organization of professional development of educators, in particular: scientific-methodological polylogue in interactive formats, sessions of selectors, centers of andragogic skills, trainings on development of creativity, round tables on the exchange of experience, conferences, webinars, chats, on-line studios, creative web-quests, workshops, organization of international cooperation on problems of development of andragogy, realization of joint educational and scientific projects in the virtual space.

More detailed systematic analysis of these guidelines and trends in the development of creativity of scientific and pedagogical workers, the introduction of groups for the development of creativity of specialists in the system of postgraduate education, as well as phased scientific and methodological support for their professional development and self-development, form the prospects for further scientific research.

\section{REFERENCES:}

1. Джонс Дж. К. Методы проектирования / пер. с англ. Т.П. Бурмистровой, И.В. Фриденберга. 2-е изд. доп. Москва : Мир, 1986. 326 с.

2. Ілляхова М.В. Розвиток креативної компетентності педагогічних працівників у системі післядипломної освіти : спецкурс. НАПН України, ДВНЗ «Ун-т менедж. освіти». Київ, 2015. 68 с.

3. Ілляхова М.В. Андрагогічні принципи фрормування креативної особистості. Обдаровані діти - інтелектуальний потенціал держави : матеріали Міжнародної науково-практичної конференції, 16-20 вересня 2014 року, м. Київ. Київ : Ін-т обдаров. дитини, 2014. С. 252-259.

4. Сорочан Т.М. Розвиток професіоналізму педагогічних працівників у системі післядипломної освіти на андрагогічних засадах. Розвиток післядипломної педагогічної освіти України в умовах інтеграції : матеріали щорічної звітної Всеукраїнської науковопрактичної конфреренції, присвяченої 15-річчю АПН України, 11-12 квіт. 2007 р. Донецьк : Донецький обл. ІППО, 2007. С. 132-140. 